\title{
Sociologie jako vědecký základ ustavení Československa v roce 1918 - Masaryk, Chalupný, Bláha ${ }^{1}$
}

\author{
Sociology as a Scientific Basis for the Foundation \\ of Czechoslovakia in 1918: TGM, Chalupný, Bláha
}

Markéta Sedláčková

\begin{abstract}
The analysis of the concept of the nation, the meaning of Czech history and the concept of the newly established Czech state in the works of three important Czech sociologists - Masaryk, Chalupný and Bláha - reveals two fundamental facts. First, the requirement of political independence of the Czech nation was not only a random political initiative, but - in addition to involvement by other sciences such as history and philosophy - sociology contributed significantly to the new state's legitimacy through its scientific methods. If Masaryk emphasizes the spiritual mission of the Czech nation in legitimizing the Czech state, the legitimacy of the Czech programme of political independence arises not only from historically philosophical and ethnographic relations, but also from anthropogeographic relations, i.e. from nature itself. In his structural-functionalist analysis, Bláha acknowledges the importance of geographical and biological factors in the formation of the nation, but for him, the nation in the Masaryk tradition is primarily a cultural and spiritual community. Whatever the factor, the fundamental benefit of these sociological analyses is that efforts to shape national identity and build an independent Czechoslovak state were significantly supported by both the theoretical development of Czech sociology and its institutionalization at the beginning of the twentieth century.
\end{abstract}

KEYWORDS Czech sociology, foundation of Czechoslovakia, Masaryk, Bláha, Chalupný

\section{Úvod}

Sociologie se jako věda ustavuje v druhé polovině devatenáctého a na počátku dvacátého století a již od svého počátku je prezentována nejen jako akademická disciplína, ale také jako objektivní vědecký základ pro řízení společnosti. Tato očekávání do sociologie vkládal již její duchovní otec, Auguste Comte. Sociologie měla dle jeho klasifikace věd stát na samém vrcholu žebříčku jakožto nejkomplexnější věda, která dokáže exaktními metodami analyzovat společnost, po vzoru př́rodních věd definovat její zákonitosti a díky tomuto poznání léčit její

Sociální studia / Social Studies SPEC/2020. S. 89-104. ISSN 1214-813X.

1 Tento text prošel prvním kolem recenzního řízení v časopise Sociální studia / Social Studies, jeho autorka však již neměla př́íležitost jej revidovat a dopracovat do finální podoby. Markéta Sedláčková zemřela v dubnu roku 2020. 
neduhy. V tomto smyslu na Comta navazovali i mnozí čeští sociologové počátku dvacátého století. Sociologie se etablovala nejen jako nový vědní obor, ale rychle se stala i velmi populární, byla přednášena jak na univerzitách a vysokých školách, tak se postupně zařadila i mezi obecné středoškolské vzdělání, a byla dokonce propagována jako nástroj, jímž by měl být vybaven každý politik i běžný občan demokratického státu. Příznačný je fakt, že první i druhý československý prezident byli sociology, jako i mnoho dalších důležitých veřejných postav první republiky: Jan Šrámek, Milan Hodža, Antonín Štefánik, Lev Winter a další.

Z titulu vědeckého základu politického jednání jí bylo, spolu s dalšími obory, svěřeno hledání smyslu českých dějin a legitimizace nového československého státu. V následující stati bych ráda přiblížila pojetí uplatnění sociologie při utváření koncepce Československa u Tomáše Garrigua Masaryka a jeho následovníků Emanuela Chalupného a Inocence Arnošta Bláhy. Jak Masarykův, Chalupného, tak i Bláhův způsob sociologické analýzy klade nejprve otázku po roli sociologie, obecněji po roli sociálních věd ve společnosti, vztahu sociologie a politické praxe. Vzhledem $\mathrm{k}$ šiři tématu se $\mathrm{v}$ tomto př́spěvku zaměřím $\mathrm{v}$ jejich koncepcích zejména na pojem národa, národního charakteru, státu, pokroku a demokracie.

\section{Česká otázka a světová, sociologicky podložená odpověd' - TGM}

\section{Lidskost Masarykovy sociologie versus Comtův pozitivismus}

Masaryk jakožto zakladatel české sociologie z Comtova sociologického systému vychází a navazuje i na jeho představu sociologie jakožto moderního vědeckého nástroje sloužícího nejen k poznávání společnosti, ale i $\mathrm{k}$ jejímu přetváření a řešení sociálních problémů (napřr. Theorie a praxis, 1876 a Základové konkrétní logiky, 1885). I přs návaznost na francouzského sociologa najdeme u Masaryka některé významné odlišnosti, které jsou zásadní pro formování české sociologie i pro její roli, kterou sehrála v legitimizaci ustavení Československa v roce 1918. Masaryk sice chce sociologii jako moderní vědu na exaktních základech, na druhou stranu ale kriticky pohlíží na její dosavadní vývoj, který se až př́liš snaží připodobnit přírodním vědám (výmluvný je již její původní název „sociální fyzika“). Comte navíc vyjímá z klasifikace věd psychologii, kterou ze svého pozitivistického hlediska podřazuje biologii (Masaryk 1901, s. 6). Oproti tomu Masaryk psychologii považuje za vědu sociologii velmi blízkou a jí také užitečnou, dle něj nelze lidskou společnost zkoumat jen zvnějšku jako prírodu, ale nahlížet ji i zvniť̌ku, nebot' „divák člověk se také musí dívat do sebe“ (Masaryk 1901: 7). Zároveň poukazuje na odlišnost př́rodních věd, které lze objektivisticky a věcně seřadit, a duchověd, mezi nimiž se poměry vzhledem $\mathrm{k}$ jejich specifickému charakteru různí. Velmi těsný vztah vidí mezi jevy sociálními, historickými a psychickými (Masaryk 1901, s. 173) a spolupráce těchto věd je pro něj při zkoumání společnosti, jakož i otázky národní, klíčová.

Vedle comtovského pozitivismu se Masaryk vymezuje i vůči francouzskému sociologismu, tedy pojímání sociálních faktů jako samostatně existujících nadindividuálních jevů. Sociologismus, který byl v Masarykově době nejvýrazněji reprezentovaný Émilem Durkheimem, byl jasně kritizován např́klad i Benešem či dalšími a v české sociologii nebyl prakticky nikdy zcela přijat. Přestože i v definování této nové vědy Masaryk vychází 
z Comtova rozdělení na statiku a dynamiku, jeho definice sociologie jako „výkladu sociálních vlastností člověka a sociálních sil, otázka po tom, co společnost za stálého vývoje udržuje“ (Masaryk 1901: 104) akcentuje vztah mezi jedincem a společností (Kozák 2018, s. 28). Typicky je tento odlišný úhel pohledu vidět také na tématu náboženství, kterým se Comte či Durkheim primárně zabývají jako sociálním systémem, nadindividuálním společenským konstruktem, zatímco Masaryk řeší především vztah jedince $\mathrm{k}$ náboženství, možnost rozvíjení duchovního rozměru člověka a tím jeho celistvosti, důležité i celospolečensky. Masaryk se nezabývá náboženstvím pouze intelektuálsky, je pro něj věcí mravnosti, věcí životně neodbytnou (Bláha 1997, s. 38) pro jednotlivce i, jak ukážeme dále, pro národ. I jeho studie Sebevražda (1881) sice obsahuje sociologickou analýzu poměrů biologických, geografických, obecně společenských, politických i hospodářských, ale skrze ně Masaryk pouze směřuje $\mathrm{k}$ rozboru poměrů duchovní kultury, tedy vzdělání rozumovému, mravnímu i náboženskému, které považuje za stěžejní. Jeho závěr, že přičinou stavu moderní společnosti, v níž se sebevražda stala hromadným jevem společenským, je polovzdělanost a beznábožnost doby (Masaryk 2002, s. 181), se kupř́kladu dnes jeví jako mnohem nadčasovější než teze Comtova a mnoha Masarykových současníků, pro které pokrok znamenal překonání náboženství a absolutní dominanci vědeckého světonázoru.

Nejmarkantnějším, a pro téma tohoto uvažování nejzásadnějším je rozdíl mezi Comtovým požadavkem ,pouhé“ vědecké kauzality a Masarykovým požadavkem teleologického výkladu společenských jevů. Jestliže cílem Comtovy sociologie je sledování př́icinných souvislostí společenských jevů a formulování zákonů po vzoru prrírodních věd, Masaryk, jak jsme již výše naznačili, se odmítá spokojit s pouhým vnějším objektivistickým pozorováním společnosti. Na rozdíl od Comta, který dle Masaryka „,svou pozitivistickou policií přemýšlení a pátrání po smyslu zakázal“" (Masaryk 1901: 823), Masaryk považuje teleologický výklad pro sociologii za nezbytný. Vzhledem k tomu, že ve vědách týkajících se lidí je možné se opírat o vnitřní porozumění jednání jedince a odkrývat jeho účel a smysl, pak je logické snažit se odkrývat i smysl celých společností, a pokoušet se dokonce i o rozkrytí „koexistence příčin a faktů posledních“ (Masaryk 1901: 738), které jsou neproniknutelné a člověku nesrozumitelné. V tomto smyslu je úlohou sociologie také ospravedlnění existence nově se ustavujícího státu československého a porozumění jeho úloze v dějinách.

\section{Spor o smysl českých dějin, sociologie versus historie}

Spor o smysl českých dějin se v české společnosti rozhořel již ve druhé polovině devatenáctého století a na obrátkách získal diskusí ohledně pravosti rukopisů Zelenohorského a Královedvorského, údajně dokládajících dlouhou historii českého národa. Masaryk do této diskuse vstoupil právě z pozice sociologa, a to na stránkách jím založeného periodika Atheneum, které si kladlo za cíl popularizaci aktuálních vědeckých poznatků, zejména sociologických. Požadoval vědeckou analýzu dokumentů a sám podal sociologický rozbor zpochybňující jejich pravost, čímž si zneprátelil široké vlastenecké kruhy (Nešpor 2011, s. 21). Masaryk svým př́istupem jasně ukázal, že i když pro něj historická legitimizace českého národa byla jedním z důležitých sociologických cílů, nemohlo se tak dít na základě pochybného dokumentu. 
Masaryk se věnoval řešení smyslu českých dějin soustavně a dlouhodobě, nebot' ho považoval za nutný podklad pro praktickou politiku př́padného budoucího českého státu. Celá jeho tetralogie z let 1895-1896 - Česká otázka, Naše nynějši krize, Karel Havlíček Borovský a Jan $H u s$ - konstruuje smysl českých dějin jako rozvíjení nábožensky zakotvené humanity pramenící v české reformaci. Tato Masarykova teze se setkala s mnohou kritikou. Hned v letech devadesátých např́iklad prostřednictvím jeho blízkého spolupracovníka Josefa Kaizla, který vyčítal Masarykovi ahistorismus s poukazem na historickou návaznost českého obrození na josefínské osvícenství, a ne na dávné husitství. Později, za první republiky, to byl především historik Josef Pekař, který kritizoval Masaryka z pozitivistických pozic za nevědeckou konstrukci dějin.

Je ale třeba říci, že Masaryk tuto konstrukci vytvářel vědomě a oproti historickému empirismu, ,pouze“ sbírajícímu fakta, stavěl požadavek hledání vyššího smyslu ve spoustě faktů, nebot' fakta mají dle něj i jakési podhoubí, tzv. „stav duchovní, z něhož se čin či událost rodí“‘ (Masaryk 1901: 826). Jako př́klad uvádí Jana Husa, od jehož reformačních postojů odvozoval smysl českých dějin, a podotýká, že historik přece nemůže jen konstatovat, kdy a kde byl Hus upálen, ale musí zkoumat i pohnutky - Husovo úsilí o lidskou mravnost, jeho svědomí, svědomí jeho oponentů, nebot' dle Masaryka svědomí jednotlivců utváří zároveň i svědomí celé společnosti. Je proto třeba znát podstatu předmětu, o kterém píšeme, zamýšlet se filozoficky nad během dějin. Vědecký historik se má řídit Tocquevillovým pravidlem: „Je parle sur 1'histoire et ne la raconte pas“ (Hovořím o historii, jen ji nepřrř́kávám [Masaryk 2001: 99]). Za důležitou považuje spolupráci historie a sociologie, kdy indukčnější postup konkrétní historické vědy je důležité doplnit abstraktnější a více syntetizující sociologií, stavějící spíše na dedukci (Masaryk 1901, s. 827). Právě takovýmto zpo̊sobem lze argumentovat existenci českého národa, která pro Masaryka nebyla ničím daným, ale bylo zapotřebí z dějin vybírat události, které vedly k utváření národa, a spojovat je v určitý smysl.

Vedle požadavku hledání smyslu a spojení induktivní metody s deduktivní klade Masaryk historii požadavek ,studovat více přítomnost než minulost, [...] vykládat minulost př́itomností, nikoli přítomnost minulostí“ (Masaryk 1901: 905). Tento na první pohled nelogický postup argumentuje Masaryk tím, že přítomnost je nám známější a př́istupnější díky přímému svědectví lidí. Ve své České otázce dokonce z těchto pozic kritizuje i jinak jím vyzdvihovaného Palackého, když poznamenává, že i jeho historismus zavedl na dráhu velmi konzervativní a český národ má tendenci se obracet více do minulosti než do př́itomnosti či budoucnosti (Masaryk 2000, s. 108). Naopak Masaryk se odkazuje na Havlíčka, zdůrazňuje potřebu pohledu do budoucna, vystavěného na filozofickém základu kritického realismu. Hlavním pravidlem realismu je poznávat vždy a všude věci a jejich jádro, vývoj věcí, zatímco jejich historická změna je druhotná (Masaryk 2000, s. 109).

Sociologii Masaryk dále považuje za základní průpravnou vědu jak pro historiky, tak pro ostatní odborníky konkrétních sociálních věd (Masaryk 2000, s. 908). Spojení sociologie a historie navíc může napomoci sociologii ke schopnosti vypozorovat opakující se společenské trendy, což bylo pro Masaryka předpokladem pro sociologické vymezení společenských zákonů a pravidel, tedy pokroku vědy a do budoucna i možností předvídání vývoje společnosti (Kozák 2018, s. 35). V otázce předvídání upozorňuje na nutnost rozlišovat jasně mezi fatalismem a determinismem. Sociologické poznávání a ustavování historických a sociálních 
pravidelností, zákonů, neohrožuje svobodnou vůli člověka, nevede k fatalismu. „Fatalism tkví v nepředvídání a tkví v pasivitě, kdežto determinism naopak nutká k aktivnosti““ (Masaryk 1901: 735). Fatalista je dle Masaryka ten, který věří, že jeho chtění se vynořuje z jeho nitra nezávisle na prríčinách sociálních, zatímco determinista si je vědom, že jeho jednání je okolím omezeno, ale že skrze poznání příčin, sociálních podmínek a uvědomění si našich omezení máme moc a svobodu naše chtění prosazovat. Na základě fatalistického či deterministického př́istupu k životu hodnotí Masaryk i jednotlivé evropské národy. Fatalismus je typičtější pro katolické národy, zatímco determinismus pro národy s reformační vírou, zejména kalvinistickou (Masaryk 1901, s. 735-736). Deterministický př́istup je dle Masaryka jednou z klíčových př́čin moderního národního charakteru vyznačujícího se pracovitostí, energií a nepasivitou.

\section{Pojetí národa, česká otázka a světová odpověd"}

Ve své koncepci národa vychází Masaryk z Herderova preromantického pojetí národa jako jakési vyšší kolektivní osobnosti vnášející do dějinného vývoje něco svého, osobitého. „Národ - národ není abstraktum, jež si každý z čistého egoismu vytvoří sub specie sui, ale ty, on, já, my všichni jsme národ“ (Masaryk 2000: 295). Navazuje na Herderovu myšlenku, že instituce může národ spojit $\mathrm{v}$ celek pouze politický, ovšem jednotu jeho kultury vytvářejí právě jen tvůrci (Bojda 2015, s. 83). Masaryk definuje národnost jako výsledek spojení vnějších, sociálních faktorů, a vnitřních, psychických faktorů (Kozák 2018, s. 28). Toto vymezení je zcela $\mathrm{v}$ souladu $\mathrm{s}$ imperativem kritického realismu poznávat věci nejen vně, ale i do hloubky, vnitřně. Jak vysvětluje v Podstatě a methodě sociologie v oddíle o příčinách a soupříčinách sociálních jevů, „sociálně historické dějstvo je účinem dvou kategorií sil: vnějšś prrírody a vnitřní prírody lidské, tělových a duchových vlastností“ (Masaryk 1901: 665). Trapl v knize Masarykův program (1948) hodnotí jeho pojetí národa jako „ani naturalistické, ani krajně objektivistické“. Přestože Masaryk uvažuje i o př́rodní podmíněnosti, je pro něj jen předpokladem $\mathrm{k}$ výtvoru lidského ducha, který je zejména produktem myšlenkové práce a kulturní tvořivosti (Trapl 1948, s. 152). Národní uvědomění, a v tom opět Masaryk navazuje na Herdera, tedy emancipace národa, nepřichází odněkud shora, ale děje se skrze emancipaci člověka-občana. Nositelem pokroku a národní kultury, je ten, „kdo je nejvíc tím, kým právě je, tzn. imanentně nacionálně definovaným člověkem“ (Bojda 2015: 83). V díle Naše nynějši krize např́klad Masaryk argumentuje, že jakýkoli student pracuje pro národ již tím, že se svědomitě připravuje na své budoucí povolání (Masaryk 2000, s. 294). A co je to osobité, specifické pro národ český? Na to Masaryk odpovídá především ve svém díle Česká otázka.

V předmluvě k České otázce (1895) Masaryk zdůrazňuje, že záměr jeho analýzy není prvotně politický, ale že mu jde především o ,sociologický rozbor všech těch záhad, jež vnucují se tomu, kdo postihnout chce smysl české historie, kdo poznat chce, čím jakožto zvláštní národ kulturně žijeme, co chceme, co doufáme“ (Masaryk 2000: 11). Na základě sociologického vědeckého poznání je teprve možné vytvořit národní politický program, formulovaný s osobní odpovědností a na základě humanismu, takový, aby ho mohl přijmout každý člověk. Masarykovou snahou bylo jednoznačně vystavění pevnějšś ideové báze, než jakou představovalo dobové nacionalistické smýšlení. Cílem pro něj bylo hlubší pojetí češství, sociologické 
a dějinně filozofické promyšlení ideje národa, jeho postavení v celku lidstva a formulování smyslu českého dějinného a kulturního úsilí (Trapl 1948, s. 152). Český program humanitní vychází dle Masaryka z cílů, tužeb a ideálů obrozeneckých a reformačních (Masaryk 2000, s. 347). Na základě rozboru života a díla českých historických osobností, jako byl Hus, Chelčický, Komenský, Havlíček či Palacký, Masaryk shrnuje typické vlastnosti pravého českého člověka (Bláha 199, s. 41). Ideálem jsou mu vědeckost, svoboda myšlení a mravnost jednání.

Národní program by navíc neměl být tvořen jen pro př́slušníky daného národa a v tomto smyslu Masaryk prohlašoval, že „česká otázka je bud' otázkou světovou, anebo otázkou není“ (Masaryk 2000: 210). Přestože členové národa cítí lásku k půdě, k danému jazyku, ke společné ideji národní, specifická idea národnostní má přispívat v Masarykově pojetí $\mathrm{k}$ ideji humanitní (Trapl 1948, s. 153). I zde vychází z fillozofie Herderovy, která vymezuje pokrok vzestupem $\mathrm{k}$ ideálu univerzálnímu, ne jen subjektivně nacionálně vymezenému, a v důsledku vede $\mathrm{k}$ humanistické legitimizaci národního sebeurčení (Bojda 2015, s. 84). Ve svých dílech Slovanské studie (1889), Rusko a Evropa (1913) - proto Masaryk považuje za nezbytné zabývat se vztahem $\mathrm{k}$ ostatním slovanským národům a vztah $\mathrm{k}$ nim nově založit na věcnosti, pravdivosti a bezpečném poznání (Bláha 1997, s. 41). V díle Nová Evropa (1918 a 1920), které se rodí již spolu s novým státem československým, se zabývá národním programem v mezinárodním významu. Věnuje se zejména konkrétním budoucím očekáváním Čechů a Slováků: nabytí nezávislosti a obnovení státu zemí českých se Slovenskem, poválečnému uspořádání Rakouska-Uherska, české samostatnosti jako součásti politické a sociální organizace Evropy a lidstva (Bláha 1997, s. 42-44). V tomto ohledu Bláha hodnotí Masarykovu osobnost i jeho dílo jako dovršení buditelského období národních dějin a zahájení nového období nadstavbou světovosti.

\section{Sociologie a politika: teorie a praxe}

Vědu a politiku Masaryk nevnímá jako dva oddělené, či dokonce opozitní světy, ale vědecká př́íprava je podle něj př́pravou pro život i pro činnost politickou (Masaryk 2000, s. 301). Věda má mít sociální poslání, nebýt jen vědou pro vědu, ale z vědecky dosažených poznatků má vyvozovat důsledky pro společnost a její organizaci (Trapl 1948, s. 180). Proto je sociologie nutným základem vzdělání politického či sociálního (Masaryk 1901, s. 179). Již ve svém raném díle Theorie a praxis chápe Masaryk sociologii jako cestu ke společenskému pokroku, a to právě prostřednictvím politiky. Důraz na spojení sociologie jako teorie a politiky jako jejího praktického uplatnění byl na veřejnosti někdy interpretován jako využití sociologie pro čistě české národnostní a státotvorné cíle (Kozák 2018, s. 39). Ve skutečnosti je nesporné, že v době vydávání Theorie a praxis v roce 1876 byl Masaryk jednoznačně monarchistou, jak poznamenává Kozák, a i v pozdějších obdobích ve svých dílech jasně zdůrazňoval, jak kritičnost a univerzálnost vědeckého bádání, tak i, jak jsme uvedli výše, chápání otázky české jako otázky humanitní, jako „otázky po osudech člověčenstva“ (Masaryk 2000: 11).

Přestože v reálné politice se Masaryk aktivně zasazoval o samostatnost a sebeurčení českého národa, včetně svézákonnosti (např́klad jeho řeč v parlamentu 18. 11. 1892, 20. 3. 1893, první otevřené protirakouské vystoupení ve Švýcarsku v Ženevě 6. 7. 1915 
na Husových oslavách [Trapl 1948, s. 171-175]), spása národa pro něj nespočívala v pouhém státním právu. Pro moderního člověka, jak zdůrazňuje ve svém díle Naše nynějši krize (1895), má být stát ,jedním z kulturních činitelů společenských“ (Masaryk 2000: 272), není to fetiš či všemohoucno. Za ,primum necessarium“ pro stát Masaryk považuje vzdělání a mravnost (Masaryk 2000, s. 273). I proto nesouhlasí s konceptem náhlé revoluční změny, a již v Rámcovém programu české strany lidové z roku 1900 se dovolává Havlíčka a jeho praktik zákonného odporu, pokrokových taktik politických a zejména důrazu na práci, mravnost a vzdělanost (Trapl 1948, s. 171). Upozorňuje, že politická samostatnost není samospasitelná, stát nelze uskutečnit ze dne na den, nebot' po jeho vytvoření je také třeba jej udržet (Trapl 1948, s. 173) a ,politickou samostatnost využít k své samobytnosti a k duchovní samostatnosti“" (Masaryk 2000: 92).

Jedna ze zásadních podmínek udržení existence moderního demokratického parlamentárního státu spočívá dle Masaryka v politicky a všeobecně vzdělaném a uvědomělém voličstvu (Masaryk 2000, s. 196). Jím hlásaný realismus má být kromě metody i směrem, který se má pokusit ,znárodnit všecku vědu a filozofii, [...] vědu učinit přístupnou všem vrstvám národa, [...] je to protest proti monopolu vzdělání, realismus chce vědecké a fillozofické vzdělání socializovat“" (Masaryk 2000: 117). Masaryk v Naší nynějši krizi konkrétně zmiňuje, že v pokročilých státech se např́klad reformují studia právnická a zavádějí se vyšší a nižší školy sociologické a politické (Masaryk 2000, s. 196). Vedle čistě vědeckého přínosu z Masarykova díla jasně vyplývá, a to již i z rané Theorie a praxis (Kozák 2018), snaha naučit českou společnost prostřednictvím sociologie sociálně myslet i cítit. Právě tento přístup u Masaryka Bláha obdivoval a analyzoval ho jako Masarykovu schopnost vidět do skutečného člověka i dění sociálního a osvícenské myšlenky zrealističtit díky sociologii, slovanství, životní zkušenosti a možná i sociálnímu původu (Bláha 1997, s. 44-45). Lze říci, že Masaryk pro Bláhu zosobňoval platónskou představu politika, spojení filozofa a muže činu.

\section{Demokracie pramenící v reformaci}

Filozoficky považoval Masaryk za ústřední problém českých dějin otázku humanitní, pojímanou především jako otázku náboženskou a mravní. Víru chápal jako vnitřní, duchovní zakotvení člověka a usilování o hlubší člověčenství, vůči církevním strukturám byl naopak velmi kritický. Za důležitý český přínos lidstvu považoval reformační myšlenky, nebot' odkazovaly k větší svobodě myšlení, osobní odpovědnosti a toleranci vưči druhým. Ve svém díle Jan Hus vymezuje humanitu tímto imperativem: „V každém člověku ctít musíme sobě rovného - to je humanitní ideál našich buditelů, to je jejich ,čisté člověčenství'..." (Masaryk 2000: 344). V tomto smyslu považoval Masaryk reformaci za předpoklad utváření demokratické společnosti.

Pojímat stát demokraticky a lidově, jak jsme naznačili již výše, znamená přestat ho pojímat jako bytost mimospolečenskou či nadspolečenskou, pojímat jej konkrétně a reálně. Politické funkce - centralizující, spravující, kontrolující - jsou významné, ale silnější jsou dle Masaryka funkce náboženské, osvětové, vědecké a mravní (Masaryk 2000, s. 194-196). Masaryk však není jen idealistou, ale sám sebe označuje za realistu. Ideové semknutí českého národa je pro něj možné jen ve společnosti s ne př́liš velkými sociálními rozdíly. Proto je 
třeba ve státě usilovat o větší politickou, hospodářskou, kulturní a především sociální rovnost. Otázka česká je zároveň otázkou sociální, kterou je nutno řešit prakticky, i když její ukotvení by nemělo být materialistické, ale mravní (Masaryk 2000, s. 155-159). Jak poznamenává spisovatel Jaroslav Boček, jestliže $\mathrm{z}$ hesla Francouzské revoluce byl v následujících staletích kladen důraz zejména na svobodu a rovnost, Masaryk považoval za důležité bratrství, podobně jako Palacký. Bratrství dává svobodě meze, nebot' je založeno na sebekázni beroucí v úvahu i druhé, dokonce i sama před sebou. Ve spise Jan Hus říká Masaryk př́mo: „Náš úkol reformační a obrodní, náš úkol národní, naše idea česká je povýtce sociální - je právě bratrstvi““ (Masaryk 2000: 344). V důsledku toho se kriticky stavěl např́íklad k ideologii liberalismu, který považoval za nemravný a protispolečenský.

Demokracie pro něj nebyla jakoukoli lidovládou, ale společenským systémem sjednocujícím zákonodárství, parlament, vládu, veřejnou správu a v neposlední řadě duchovní vůli občanů $\mathrm{k}$ demokracii, kterou $\mathrm{v}$ dnešní terminologii nazýváme občanskou společností. Za úhelný kámen moderní demokratické společnosti považoval otevřenost alternativám, a proto jasně odmítal marxismus, ideologii navíc ryze materialistickou, či ruskou teokracii založenou na carismu a prolnutí státu s církví. V poslední kapitole Světové revoluce vyjadřuje zásady politiky v novém osvobozeném státě svým slavným „Ježíš ne Caesar, tot' smysl našich dějin a demokracie“, stavějícím se proti agresivitě a dobývání dialogem a humanitou. Demokracie pro Masaryka nebyla jen politickým zř́zením, ale především životním postojem, životní filozofií, vedoucí k aktivní účasti člověka na utváření světa. Pro něj zásadní problém české politiky, který popisuje již v Theorii a praxis, spočívá v pasivitě (Kozák 2015, s. 31-32). V České otázce na vývoji české politické scény v druhé polovině devatenáctého století ukazuje, že není tak jednoduché proti pasivitě bojovat jen náhlou, ideově nepodloženou aktivitou (Masaryk 2000, s. 128-129). Skutečná politika musí vycházet z hlubšího kulturního a vědeckého základu. Masaryk proto vždy klade důraz na vzdělání budoucích českých politiků, na jejich osvojení si sociologických znalostí o české společnosti. Sociologie, která si dokáže všímat věcí nepatrných, na které obyčejný člověk jinak nedává pozor, a přesto jsou pro život společenský zásadní, by měla vést moderního politika $\mathrm{k}$ soustř̌edění na každodenní drobnou práci oproti dř́ve požadovaným hrdinským činům (Masaryk 1901, s. 663). Z politiků by neměla vyzařovat bezmocnost vůči Rakousku, vyjadřovaná dosud zejména pasivitou, ale měli by svou erudovaností a aktivitou dodávat lidu důvěru, být mu otevření. Masaryk pasivitu spojuje také s jakýmsi kultem mučednictví, konceptem francouzského historika Ernsta Denise, popisujícím tendenci Čechů se po určitém nezdaru místo dalšího aktivního úsilí raději uchýlit do role ublížené oběti (Masaryk 2000, s. 151). Masaryk apeluje na to, abychom svou nespokojenost neobraceli jen navenek, ale hledali příčiny nezdaru především v sobě (Masaryk 2000, s. 208).

Důležitou součástí vybudování nového státu je pro Masaryka i tzv. nepolitická politika v podobě všednodenní kultivace vztahů mezi lidmi, průběžného demokratizování a zlepšování života, které mohou představovat jakousi prŕípravku občana k př́padné politické práci. Za vybudováním sebevědomého českého národa a moderního demokratického státu československého musí stát odhodlání každého občana říci si: „I já jsem stát, národ, lid, [...] a co tedy žádá po státu, národu a lidu, plniž především sám ve svém kruhu stálých povinnosti““ (Masaryk 2000: 208). 


\section{Socio-geografická legitimizace československého státu - Emanuel Chalupný}

Jestliže Masaryk zdůrazňoval při legitimizaci českého státu duchovní poslání českého národa, jeho žák Emanuel Chalupný se ve svém sociologickém uvažování o podobě nového českého státu zaměřuje na objektivované složky kultury, konkrétně jazyk, a také na vnější přírodní prostředí. Vztah Chalupného k Masarykovi nebyl jednoznačný. Chalupný byl návštěvníkem Masarykova semináře, ale ne přímo jeho žákem. Metodicky mu byl zřejmě nejbližším pokračovatelem a navazoval na jeho témata jako národ, český stát, husitství, ne však nekriticky (Petrusek 1999, s. 67). I přes někdy téměř urážlivé výroky vůči Masarykovi, a to až osobního charakteru, se Chalupný rád stavěl do role završování Masarykova sociologického odkazu a ve třicátých letech shrnul jeho prrínos pro českou sociologii vcelku pozitivně. Pro naše téma je důležité zejména to, že Chalupný přiznává Masarykovi roli zakladatele české sociologie, uznává př́nosnost jeho sociologických rozborů - zejména rukopisů, národní situace a válečné národní i světové situace - a v neposlední řadě oceňuje Masarykova propojení teorie s praxí, tedy sociologie a politiky (Petrusek 1999, s. 68). Ve výkladu Chalupného pojetí role sociologie při budování nového státu $\mathrm{v}$ této stati vycházíme zejména z jeho díla Národní povaha česká (1907) a Český stát z hlediska sociologie (1918). Myšlenky podobné těmto studiím lze nalézt $\mathrm{v}$ dalších Chalupného pracích týkajících se české národní otázky, jako například Úkol českého národa (1910) či Vltava (1914).

\section{Zkoumání národní povahy skrze objektivované složky kultury - jazyk}

Snaha o vytvoření objektivního vědeckého podkladu pro vytváření politiky, konkrétně koncepce nového státu, byla Masarykovi a Chalupnému společná. Jestliže u Masaryka spadala do sféry pozitivity i realita idejí, kterou považoval za klíčovou složku základu sociálního jednání a kultury, Chalupný chápal pozitivitu více naturalisticky, v tradici Ludwiga Gumplowitze (Havelka 1999, s. 96-97). Jak jsme ukázali v předchozím oddíle, Masaryk klade důraz na historické a kulturně podmíněné mravní jednání, zatímco Chalupný se soustředí více na objektivované složky kultury, a navíc $\mathrm{v}$ sepětí $\mathrm{s}$ př́rodním prostředím. To dobře odráží i jejich odlišné pojetí postavení sociologie mezi vědami, kdy přes společnou blízkost psychologii považoval Masaryk za spřízněnou především filozofii a historii, zatímco pro Chalupného to byla biologie. Chalupný zavádí pojem regionality a regionální sociologie, která má vycházet z poznání reálných vztahů člověka a př́rody, a to pomocí syntetizace poznatků ekologie, biologie a psychologie. Přestože regionální sociologie vyrůstá z př́rodního a antropologického základu, Chalupný tento př́stup aplikuje na vysvětlení hospodářských, politických a náboženských jevů (Pauza 1999, s. 82-83). Regionální sociologie tak nemá být pouze vědou, ale i regulativním nástrojem dané společnosti, prostředkem porozumění sama sobě a svému národnímu společenství. V tomto smyslu je Chalupného koncepce jistou obdobou Masarykovy filozofie českých dějin, přestože Masaryk hledá jednotící národní prvek v náboženském odkazu, zatímco Chalupný ho vidí v každodenně užívaném jazyku (Pauza 1999, s. 84). Sociálně psychologické složky národní povahy jako mentalita, temperament jsou ve vývoji dle Chalupného nahrazovány stále více objektivovanými sociologickými složkami kultury jako např́íklad politika, náboženství či umění (Havelka 1999, s. 98-99). Sociologické zkoumání národní povahy soustřed'ující se na ustálené kulturní útvary proto Chalupný 
považuje za významnější než zkoumání historické, které zachycuje více jednotlivosti než typičnost. Nejtypičtějším kulturním útvarem byl pro Chalupného jazyk, nebot', ,jako nezbytná spojka života společenského, je zároveň pokladnicí tvorby kulturní“ (Chalupný 1932: 27-28). Charakter Čechů vyvozoval z přízvuku českého jazyka na první slabice, což spojoval s tzv. českou anticipativností. Důraz na počátek má poukazovat na průkopnictví, schopnost brzké orientace $\mathrm{v}$ problému, duševní hbitost, rychlé vzepětí apod. Počátečnost je ale dialektickým pojmem. Přednosti vážící se k anticipaci mají i svou odvrácenou stranu, jako je nedočkavost, podceňování těžkostí cesty, nedokončování plánů či zbrklost. Jak výstižně shrnuje veškeré Chalupného př́klady dokládající jeho koncept Miroslav Pauza: „Anticipačnímu vědomí nechybí talent, ale vytrvalost“ (Pauza 1999: 85).

\section{Český stát z hlediska sociologie}

Svůj spis Český stát z hlediska sociologie z roku 1918 sám Chalupný označuje za „,prolegomenu ke každé prríští české politice, která bude moci vyhovovat výzkumům vědy sociologické" (Chalupný 1918: 3). Snaží se zde pomocí socio-geografické analýzy ukázat, že požadavek české politické samostatnosti není jen náhodnou politickou iniciativou a „nijak nezávisí na nahodilé formulaci, které se mu roku 1917 dostalo, ani na prostředcích, kterými politikové čeští se ho domáhali“ (Chalupný 1918: 4). Paradoxně se tím z dnešního pohledu dostává oproti Masarykovi spíše o krok zpět, nebot' se vrací ke Comtovi ve snaze o budování sociologie po vzoru př́rodních věd a hledání neměnných zákonů společnosti. Podobně jako př́rodní vědy daly lidem vládu nad př́rodou, je úkolem sociologie vytvořit vědecký podklad, který povede $\mathrm{k}$ formulaci koncepce kteréhokoli státu, tedy i českého státu, a tudíž i $\mathrm{k}$,zdokonalení zákonodárství i správy a k vnitřnímu i vnějšímu zesílení státư“ (Chalupný 1918: 5). Přestože Chalupný v úvodu deklaruje cíl hledat objektivní vědeckou pravdu, nadnárodní a nezávislou na politice, jeho výklad poměrů kulturních i prírodních se ukazuje jako více než subjektivní a vlastenecky ovlivněný.

Dle Chalupného nemusí být pro stát rozhodující národnostní složení a zdůrazňuje, že to není jen politický a společenský útvar, ale i území (Chalupný 1918, s. 15). Ve své analýze se opírá především o geografické poměry střední Evropy - horstva, údolí, povodí - a zároveň sleduje historické proměny území českých zemí. České území vymezuje třemi povodími Moravou, Labem a Odrou (Chalupný 1918, s. 9). V dalších úvahách ale přemítá o možné přirozené hranici dané Dunajem a dosti odvážně argumentuje, že Dolní Rakousy a většina Vídně patří prakticky v populační sféru Čech a Moravy, nebot' jsou to kraje dosti počeštěné, hospodářsky udržující Vídeň (Chalupný 1918, s. 33-34). Překvapivě se nerozpakuje uvažovat i o horní části Mad’arska, neb mezi Slovenskem a Mad’arskem žádná přirozená geografická překážka neleží (Chalupný 1918, s. 50). Tyto úvahy už nám mohou právem připadat přemrštěné a pravdou je, že i v době Chalupného se tyto návrhy nesetkaly s pochopením, na což si samozřejmě naříkal. On sám naopak považoval za oportunistické návrhy existence českého národa v rámci Rakouska, které se odkazovaly na Jungmanna, Palackého a Havlíčka (Chalupný 1918, s. 51-52). Na Chalupného obranu je možné ř́ici, že po krátkodobém úzce národním rozdělení středoevropských států uvažoval o opětovném sloučení do jakési podunajské federace, až se jednotlivé národy vyrovnají alespoň v základních podmínkách demokracie. 
Za klíčové dále považuje pohoří oddělující české země od Německa, přičemž situaci, kdy by tyto hraniční oblasti připadly Německu, považuje za velké neštěstí pro český národ, což koneckonců historie potvrdila. Charakter krajiny - v Čechách dosti kopcovité, hornaté se podle Chalupného odráží v české povaze (Chalupný 1918, s. 25-26). Stálým chozením do kopce se charakter otužuje, pěstuje se vytrvalost a odvaha, navíc duše se v úzkém styku s přírodou rozvíjí samostatněji a osamělost udržuje živý cit náboženský. Těsný pospolitý život v údolích mezi horami zase živí lásku k domovině. Na druhou stranu se ale dle Chalupného v kopcovité krajině českému národu nedostává dostatečného prostoru $\mathrm{k}$ dějinné účinnosti. Češi nemají kde sebrat své síly a společně se semknout, což vedlo vždy k slabosti v útoku, jak ukazuje Chalupný na české historii, kdy se Češi většinou před útoky ubránili, ale ve snahách o rozšíření státu př́liš neuspěli. Tato část úvah má již velmi spekulativní charakter, nejen z pohledu dnešních vědeckých kritérií, nebot' Chalupného teorie byla kritizována již v jeho době, zejména ze strany pražské sociologické školy, která o něm dokonce prohlašovala, že „kazí jméno oboru“. Za pozornost snad stojí alespoň úvaha, že mnohost údolí a rozeklanost krajiny horami se odráží i v mnohosti názorů politických a problematičnosti vytvoření politické jednoty, což lze opravdu považovat za dosti neměnný prvek české politiky. Otázkou zůstává, zda je to opravdu těmi horami... Chalupný svou studii uzavírá tvrzením, že vztahy sociologické - dějinně filozofické, antropogeografické i etnografické, dokazují přrirozenost a oprávněnost českého programu z 30. května 1917 požadujícího samostatnost českého státu. Uskutečnění ale podle něj brání zejména lidé, moc a vůle odpůrců a neuvědomělost, netaktičnost a neorganizovanost prŕivrženců (Chalupný 1918, s. 38). Přesto Chalupný vyjadřuje jakýsi optimismus výrokem, že ,politické chyby české minulosti, př́itomnosti i budoucnosti nemohou zmařit těch přirozených cílů národa českého, které kotví v samé přírodě naší vlasti i v tisíciletém vývoji evropské civilizace“ (Chalupný 1918: 4).

Studie Český stát z hlediska sociologie není rozsáhlá, i tak ilustruje obecný charakter Chalupného díla: přes velkou snahu o strukturovanost je dílo spíše nepřehledné, vyznačující se jakousi intelektuální neukázněností, která se projevuje snahou zachytit vše bez eliminace nedůležitého (Petrusek 1999, s. 71). Je to dílo velkolepé, ale místy dosti amatérské, navíc již ve své době vyjadřující určitý anachronismus (Nešpor 2014, s. 77), a to i ve srovnání s více jak o generaci starším Masarykem. Přesto se Chalupnému nedá upřít originalita myšlení a jakési „geniální postřehy racionální intuice“, jak se pozitivně k jeho sociologickému dílu vyjádřil brněnský kolega Innocenc Arnošt Bláha.

\section{Sociologie jako základ budování nového státu - Inocenc Arnošt Bláha}

Již v období před první světovou válkou, jak připomíná Bláha ve své Československé sociologii, ,zájem o sociologii nebyl zcela teoretický, od studia sociologie se očekávaly některé důležité důsledky povahy praktické, zvláště politické, eugenické a euthenické, jakož i etické““ (Bláha 1997: 17). Po první světové válce bylo zapotřebí, aby se věda dala do služeb národních a pomáhala pracovat na sebezáchově daného národa. Úspěšnou organizaci nového státu a společnosti bylo nutné podpořit novou ideovou orientací ve smyslu přesných a vědeckých pojmů, což měl být úkol pro díla obecné sociologie, jak je vytvořili Masaryk, Chalupný, Král, Fischer a právě Bláha. Pro naše téma považujeme za klíčové věnovat se v souvislosti 
s Bláhovou sociologickou koncepcí zejména jeho pojmům jako: sociálně totalizační funkce sociologie, politika jako aplikovaná sociologie politiky, sociologie národa, národ jako kulturní a duchovní společenství, demokracie, role inteligence a hodnotový konsenzus.

\section{Bláhova sociologická angažovanost}

Bláhova role sociologa pro český stát byla nejen teoretická, ale byl to i jeden z nejvýznamnějších sociologů první republiky jak z hlediska propagace této vědy, tak z hlediska jejího institucionálního ukotvení. Bláhu výrazně ovlivnilo období mezi lety 1900-1903, kdy byl Masarykovým osobním žákem, přičemž vedle vlivu Masarykovy sociologie to bylo také v rovině osobního směřování a mravního zrání (Janák 2009, s. 54). Bláha od Masaryka přebral zejména zájem o mravnost, důraz na mravní individuální aktivismus $\mathrm{v}$ intencích humanismu, který se stal jeho krédem (Sedlák 1995, s. 13). Institucionálně byl Bláha spjat s Masarykovou univerzitou v Brně od jejího založení v roce 1919. V roce 1921 zde byl jmenován mimořádným profesorem sociologie, o rok později otevřel a vedl dále sociologický seminář $-\mathrm{v}$ té době druhé akademické pracoviště sociologie v Československu (Janák 2009, s. 74-75). Byl jedním z nejaktivnějších iniciátorů založení Masarykovy sociologické společnosti (1925), podílel se aktivně na vydávání sociologických prací domácích i zahraničních a v roce 1930 založil společně s Chalupným a Fischerem Sociologickou revue.

Ve svém shrnutí rozvoje výuky sociologie v meziválečném Československu Bláha zmiňuje existenci stolic sociologie na všech univerzitách i její zavedení na mnoha vysokých školách od humanitních po technické (Bláha 1968b). Hovoří o takzvané sociálně totalizační funkci sociologie, nebot' tato věda nabízí ke speciálnímu úzkému vědění i porozumění celku společnosti, a může tudíž ochránit před profesionálním aristokratismem, stavovským egoismem a pýchou, či před „fanatickou a exkluzivní vírou ve vlastní částečný program“ (Bláha 1997: 25). Za klíčové považuje v duchu Masarykově i rozšíření sociologie do osnov středních škol, jako vědy vychovávající mladé lidi k občanství. Vedle výzkumné, metodologické a systematizační role má totiž dle Bláhy sociologie i úkol praktický. Dosaženého vědeckého poznání má být použito i k cílům zdokonalovacím a reformním. Za potěšující proto považuje fakt, že roste počet těch, kteří vyhledávají sociologii ne pro ni samou, ale jako obohacení své speciální vědy, či z důvodu praktického užití v životě (Bláha 1997, s. 24-27).

K tomu se pojí i důležitost vydávání periodik jako Česká mysl, Naše doba či Sociální revue, prostřednictvím kterých může být sociologií zasaženo veřejné mínění. Pro vědu, ale i sociální práci považuje Bláha za prínosné založení Sociálního ústavu ČSR v roce 1920, který byl nejen poradním orgánem ministerstva sociální péče, ale měl i cíl propagační. V roce 1925 vznikl Masarykův ústav lidovýchovný, který se věnoval prŕmo organizaci osvětové práce a vědeckému zkoumání lidovýchovné činnosti. Vzhledem k tomu, že Bláha považoval za nejvyšší stupeň v rozvoji národního ducha rozvoj vědecký (Bláha 1997, s. 17), vznik těchto konkrétních institucí byl pro něj zároveň i dokladem pozitivního rozvoje ducha národa českého. 


\section{Sociologie národa}

Ve svém příspěvku z roku 1948 pro sympozium o slovanské sociologii Bláha rekapituluje díla a přednášky, které se doposud vědecky věnovaly konceptu národnosti, jakož i diskuse věnované přímo národnosti české, utváření, charakteru i budoucímu směřování českého národa (Bláha 1968b, s. 261-272). Jestliže dříve převažovaly dle Bláhy v pojetí národa více vnější znaky (Jungmann, Havlíček, Tyrš), u autorů jako Masaryk, Krejčí, Chalupný jsou brány v úvahu i faktory vnitřní, psychické.

Sám Bláha ve svém díle Sociologie (1968) věnuje sociologii národa samostatnou kapitolu, v níž o národu hovoří jako o společenství, které vymezují jak vnější znaky a vnější zpưsoby chování (prvek sociologický), tak i vnitřní stavy a vztahy (prvek sociálně-psychický) (Bláha 1968a, s. 79-90). Národ definuje jako množství lidských jedinců žijících v symbióze geografícké (půda), biologické (společný původ), historické (historické osudy), kulturní (kultura, především jazyk), eticko-filozofické (národní program a ideál) a politické (svoboda). Zdůrazňuje, že přestože fakta přírodní a přirozená, geografická a biologická, se na první pohled mohou jevit jako zřejmější, národ je především společenstvím kulturním a duchovním (Bláha 1968a, s. 84). Zde Bláha vyzdvihuje Chalupného spis Národní filosofie česká, kde oceňuje, že je problém národa řešen komplexně, přesto ho považuje v jistém bodě za omezující, nebot' za hlavní znak je zde označen vnější znak kulturní - jazyk. V tomto ohledu je Bláha blíže Masarykovu pojetí národa jako eticko-filozofického společenství majícího svou osobitou interpretaci smyslu dějin. I přes mnoho společných prvků v chápání národa můžeme u Bláhy v porovnání s Masarykem vnímat posun $\mathrm{k}$ více sociologicky empirickému podložení existence samostatného národa. Ta podle něj musí být založena vědecky, na „osobitém etnografickém materiálu“, kterému teprve vlastenecká „,vůle může vdechnout duši“ (Bláha 1968a: 89). Bláha ale upozorňuje, že ani vědecké podložení národa, ani idea sebeurčení nemusí znamenat existenci samostatného státu. Ukazuje, že historicky byla vnitřní jednota, založená na vnitřním uvědomění, společném původu, jazyku, historii i kultuře, často v konfliktu s centralizující politickou státní mocí (Bláha 1968a, s. 83). Sociologicky tento fakt vysvětluje odlišností funkce státu, která je především mocenská a zaměřená k ochraně svobody uvnitř i vně státu, od funkce národa, která je kulturotvorná (Bláha 1968a, s. 87). Tímto výkladem, platným právě i pro osudy českých zemí a založeným na Bláhově strukturalisticko-funkcionalistické teorii, se Bláha ve srovnání s Masarykem či Chalupným dostává přece jen o něco blíže všemi třemi tolik skloňované objektivitě sociologického bádání, i přes svou metodu sociální introspekce a hodnotící soudy o sociálním dění.

\section{Sociologie a politika: sociologie a demokracie}

Nová politická a společenská situace vyžadovala zejména revizi obsahů národního myšlení, pojmů jako: patriotismus, pokrokovost, demokracie, státnost, vůdcovství (Bláha 1997, s. 20). Ustanovují se sociologické základy teoretické politiky a teoretickou i praktickou snahu o řešení problémů zejména politických stran, parlamentarismu či demokracie najdeme například v dílech Masaryka, Beneše, Chalupného, Bláhy, Kalába, Fischera, Mertla a dalších prvorepublikových sociologů.

Masarykovo pojetí politiky jako aplikované sociologie Bláha upřesňoval vymezením politiky jako aplikované sociologie politiky (Sedlák 1995). Sociologie politiky má odhalovat 
pozadí politických jevů, jejich determinovanost činiteli geograficko-technickými, organicko-psychickými a sociálními (hospodářské, náboženské, vzdělanostní atd.). Bláha také zmiňuje mravní rozměr politiky, dokonce jakési možné rozdvojení mezi utilitaristickými politickými cíli a mravními cíli zaměřenými na obecné blaho. Konkrétně se mravnímu aspektu politiky věnuje např́ílad v Programu Strany pokrokové z roku 1925 za účelem odůvodnění vzniku nové politické strany. Oponuje názoru, že všechny národní zájmy jsou již v různých politických stranách reprezentovány, a argumentuje, že dostatečně není „obsazen“ zájem kulturní a mravní. Jestliže přitom zájmy hospodářské a sociální společnost spíše rozdělují, síly rozumové a mravní mohou dle Bláhy naopak sjednocovat, solidarizovat a vést. Odpovědnost za osud republiky by proto měla pocit’ovat zejména inteligence, jejíž dějinná funkce je národ rozumem osvěcovat a sociálním cítěním a mravní praxí zcelovat (Bláha 1968b in Sedlák 1995, s. 158-161). Ve své monografii Sociologie inteligence (1937) Bláha vymezuje postavení inteligence v sociálním prostoru, definuje její znaky, životní styl a funkce, z nichž za klíčovou označuje funkci kulturní - vytváření hodnotového konsenzu, „duchovní atmosféry“ a „duchovních svazkư" (Bláha 1937: 58 in Janák 2009: 153). Tyto duchovní vazby jsou pro Bláhu prakticky zodpovězením klasické sociologické otázky „,jak je možná společnost“. $\mathrm{V}$ důsledku je to inteligence, která ve společnosti plní funkci tvořivě-emancipační, organizační, osvětovou, kritickou či vůdcovskou (Bláha 1937 in Janák 2009, s. 155). Z funkcí inteligence plynou úkoly zejména pro inteligenci z „hlavního povoláni'“, mezi kterou patří právě i sociologové, a úkol inteligence se tak stává i úkolem sociologie.

Sociologický př́stup založený na vědecké analýze je pro demokratickou společnost nezbytný, nebot' dle Bláhy vede „,k vyplenění sociálních předsudků a pověr, $\mathrm{k}$ umírnění sociálních vášní („,more light and less heat“), $\mathrm{k}$ předcházení a nápravě sociálních nedostatků, nesnází a chorob“ (Bláha 1997: 25). I v tomto ohledu se Bláha shoduje s Masarykem, podle něhož netolerance ve společnosti i v politice brzdí demokratický vývoj. Příčinu této netolerance a zakořeněných préedsudků vidí oba shodně v nedostatečné vzdělanosti společnosti a věrí, že společnost lze skrze sociologii vzdělat, eticky formovat a vést $\mathrm{k}$ demokratickému smýšlení a jednání. Pokrok ve smyslu „subjektivního zmocnění se výtěžků objektivního vědeckého poznání a zužitkování ho ve smyslu určitého ideálu etického $\mathrm{k}$ cíli zdokonalení a zlepšení stejně individuálního jako sociálního“ je proto u Bláhy pro demokracii klíčový (Bláha 1997: 23). Otázka pokroku v demokracii pro něj, opět v návaznosti na Masaryka, také úzce souvisí s otázkou vůdce, který by měl být nejen ideovým a organizačním vůdcem, ale i „silnou etickou osobností“. Své kroky by měl ř́dit na základě pečlivé analýzy společenské situace a díky vědeckým poznatkům anticipovat budoucí vývoj. Přestože vůdce musí dokázat lid nadchnout, jeho vize by měly vždy vycházet $\mathrm{z}$ objektivní analýzy národního vývoje a nebýt pouhou fantaskní konstrukcí, romantickou utopií, navíc primárně ř́zenou egoistickým a utilitárním zájmem. Takového politika již nelze nazývat vůdcem, ale demagogem.

\section{Závěr}

Provedená analýza pojetí národa a českého státu $\mathrm{v}$ díle třech významných českých sociologů první poloviny dvacátého století potvrzuje dvě zásadní skutečnosti. Za prvé je to fakt, že „Československo nevzniklo v roce 1918 jako náhodný výsledek mimořádně úspěšné 
akce jednotlivého dobrodružného politika“ (Šolle 1997: 89). Masaryk se zodpovězení české otázky, tedy hledání smyslu českých dějin, věnoval ve svém díle soustavně a dlouhodobě již od osmdesátých let devatenáctého století. Jeho teoretické a praktické politické dílo jednoznačně posílilo v českém národě vědomí dějinné kontinuity a vyústilo ve vytvoření moderní české politiky. Jestliže Masaryk zdůrazňoval při legitimizaci českého státu duchovní poslání českého národa, podle Chalupného oprávněnost českého programu politické samostatnosti vyplývá nejen ze vztahů dějinně filozofických a etnografických, ale i antropogeografických, tedy ze samé prŕrody. Bláha pak ve své strukturalisticko-funkcionální analýze sice přiznává důležitost geografickým a biologickým faktorům formování národa, primárně je pro něj ale národ v tradici Masarykově především společenstvím kulturním a duchovním. At' je již kladen důraz na jakýkoli faktor, zásadní př́nos těchto sociologických rozborů spočívá také v tom, že úsilí věnované formování národní identity a budování samostatného československého státu výrazně podpořilo jak teoretický rozvoj české sociologie, tak její institucionalizaci na počátku dvacátého století.

Masaryk, Chalupný i Bláha se ve svých dílech často zamýšlejí nad rolí sociologie ve společnosti. Sociologie je pro ně nejen cestou teoretického poznání umožňujícího sjednocení poznatků ze všech vědeckých i prakticko-společenských oblastí, ale je i cestou ke společenskému pokroku a vzdělanosti vedoucí ke zlepšení sociálních podmínek. Sociologická analýza má podle nich sloužit jako vědecký podklad nejen efektivního politického jednání, ale i jako osvětový nástroj rozkrývání předsudků a pověr umožňující ve společnosti větši názorové porozumění a konsenzus, na jejichž základě je možné budovat demokratickou společnost.

Sepětí Masarykovy sociologie s filozofií, projevující se v požadavku osmyslnění reality, Chalupného antropogeografie vyvozující zákony společnosti z přírodního prostředí, či naopak Bláhova metoda sociální introspekce a hodnoticí charakter jeho sociologie se na základě dnešních vědeckých kritérií mohou jevit jako neobjektivní, vědecky nepřijatelné. Víra v sílu sociologického poznání se nám dnes může zdát na jednu stranu až úsměvná a závěry tehdejších sociologů ve prospěch podpoření existence nového státu neobjektivní až zavádějící. Na druhou stranu je třeba mít na mysli, že přiřknutí smyslu vědecké analýze znamená i částečné nesení odpovědnosti za odhalené skutečnosti, možná i za další zacházení s nimi, kterému se dnes v sociologii máme tendenci spíše vyhýbat.

\section{Literatura}

BLÁHA, Inocenc Arnošt. 1968a. Sociologie. Praha: Academia.

BLÁHA, Inocenc Arnošt. 1968b. „Česká sociologie.“ Sociologický časopis 4: 261-272.

BLÁHA, Inocenc Arnošt. 1937. Sociologie inteligence. Praha: Orbis.

BLÁHA, Inocenc Arnošt. 1997. Československá sociologie. Od svého vzniku do roku 1948. Brno: Doplněk.

BOJDA, M. 2015. Herderova filosofie kultury. Herder a německé osvícenství. Magisterská diplomová práce. Praha: FF UK, FHS. Cit. 21. listopadu 2019 (https://dspace.cuni.cz/bitstream/handle/ 20.500.11956/63708/DPTX_2013_2_11240_0_421644_0_149820.pdf).

CHALUPNÝ, Emanuel. 1918. Český stát z hlediska sociologie. Praha: vl. n. 
CHALUPNÝ, Emanuel. 1905. Úvod do sociologie. S ohledem na české poměry. Praha: vl. n.

CHALUPNÝ, Emanuel. 1932. Národni filosofie československá. Národní povaha. Praha: vl. n.

JANÁK, Dušan. 2009. Hodnoty a hodnocení v sociologii Inocence Arnošta Bláhy. Brno: Masarykova univerzita.

KOZÁK, Vratislav. 2018. „Teorie a praxe. Etablování sociologie v českém prostředí T. G. Masarykem.“ Historická sociologie 10(2): 27-41.

MASARYK, Tomáš GARRIGUE. 1901. „Rukovět' sociologie.“ (+ Podstata a methoda sociologie). Naše doba 8, 1900-1901: 1-12, 98-105, 173-181, 662-667, 735-741, 822-828, 904-910.

MASARYK, Tomáš GARRIGUE. 2000 (1895-1896). Česká otázka - Naše nynější krize - Jan Hus. Praha: Masarykův ústav AV ČR.

MASARYK, Tomáš GARRIGUE. 2001 [1885]. Základové konkrétni logiky. Třiděni a soustava věd. Praha: Masarykův ústav AV ČR.

MASARYK, Tomáš GARRIGUE. 2002 [1881]. Sebevražda hromadným jevem společenským moderní osvěty. Praha: Masarykův ústav AV ČR.

NEŠPOR, Zdeněk R. 2011. Republika sociologů. Zlatá éra české sociologie v meziválečném období a krátce po druhé světové válce. Praha: Scriptorium.

NEŠPOR, Zdeněk R. et al. 2014. Dějiny české sociologie. Praha: Academia.

PAUZA, Miroslav. 1999. „Pojem regionu u Emanuela Chalupného.“ Pp. 77-88 in Josef ZUMR (ed.). Emanuel Chalupný, česká kultura, česká sociologie a Tábor (Sborník př́íspěvků ze stejnojmenného symposia, konaného ve dnech 2.-3. října v Táboře). Praha: Filosofia.

PETRUSEK, Miloslav. 1999. „Místo Emanuela Chalupného ve vývoji československé sociologie.“ Pp. 59-75 in Josef ZUMR (ed.). Emanuel Chalupný, česká kultura, česká sociologie a Tábor (Sborník příspěvků ze stejnojmenného symposia, konaného ve dnech 2.-3. ř́ijna v Táboře). Praha: Filosofia.

SEDLÁK, Jiří. 1995. Inocenc Arnošt Bláha. Brno: Nadace Universitas Masarykiana.

ŠOLLE, Zdeněk. 1997. „Význam České otázky pro Masarykovo vystoupení za války.“ Pp. 82-90 in Sto let Masarykovy České otázky (Sborník př́íspěvků z mezinárodní vědecké konference). Praha: Ústav T. G. Masaryka.

TRAPL, Miloslav. 1947. Masarykův program. Demokracie - socialismus - česká otázka. Brno: Zář.

ZUMR, Josef. (ed.). 1999. Emanuel Chalupný, česká kultura, česká sociologie a Tábor (Sborník příspěvků ze stejnojmenného symposia, konaného ve dnech 2.-3. ř́ijna v Táboře). Praha: Filosofia.

\section{Autorka}

Markéta Sedláčková vystudovala sociologii na FF UK a politologii na Sciences-Po v Paříži. Vyučovala na Katedře sociologie FF UK, kde přednášela mimo jiné Dějiny české sociologie a psychologicko-sociologický seminář Depresivni společnost. Badatelsky působila také v Sociologickém ústavu AV ČR, věnovala se zejména politické sociologii. Je autorkou mnoha článků na téma důvěra, sociální kapitál a demokracie, její stěžejní publikací je kniha Důvěra a demokracie: prehled sociologických teorií od Tocquevilla po postkomunistickou transformaci (SLON, 2012) a kapitola v mezinárodní monografii Trust in Contemporary Society (spolu s J. Šafrem, ed. M. Sasaki, Leiden/Boston: Brill, 2019). Byla členkou redakční rady nakladatelství SLON, místopředsedkyní Akademické YMCY a členkou redakční rady Křst'anské revue. 